\title{
ASYMMETRY OF THE ECONOMIC DEVELOPMENT OF CROSS-BORDER AREAS IN THE EUROPEAN UNION: ASSESSMENT AND TYPOLOGY
}

\author{
Andrzej Jakubowski \\ Institute of Social and Economic Geography and Spatial Management, Maria Curie-Skłodowska University \\ Al. Kraśnicka 2d, 20-718 Lublin: Poland \\ andrzej.jakubowski@umcs.pl
}

\begin{abstract}
The article aims to characterise the phenomenon, determine the degree, and analyse the dynamics and directions of change in the level of asymmetry of economic development of cross-border areas in the European Union (EU) based on GDP per capita (PPP). It also aims to propose a typology of cross-border areas in the EU considering the above criteria. The obtained results show that despite a relatively evident reduction of the level of asymmetry of economic development in many cases in the period 1990-2015, and particularly after 2004, many cross-border areas show significant disparities in the economic sphere. Moreover, the dynamics of the observed transformations remain spatially differentiated.
\end{abstract}

Keywords: asymmetry, borderlands, cohesion, Cohesion Policy, cross-border areas, disparities, European Union.

\section{Introduction}

European integration, creation of a common market, development of Cohesion Policy, and expansion of cross-border cooperation have led to far-reaching socio-economic changes in border areas (Anderson, O'Dowd \& Wilson, 2003). Firstly, their function has changed fundamentally - from peripheral areas they have turned into spaces of intense contacts and interactions (Ratti, 1993; Martinez, 1994; Blatter \& Clement, 2000; Blatter, 2004). The reduction of barriers resulting from the existence of traditional national borders has led to an increase in economic cooperation and trade, and development of cross-border labour markets (Niebuhr, 2004; Niebuhr \& Stiller, 2004). The development of transport infrastructure has resulted in increased population flows and trade, while support for cross-border cooperation under the Interreg programmes has led to the development of relationships between a variety of regional and local partners (Medeiros, 2018a).

A growing body of research has been developed over recent years regarding the impact of European integration and the Cohesion Policy on overcoming the peripherality of border areas, as well as on integration processes and development of cross-border cooperation in the context of border area development (Medeiros, 2015, 2018ab, 2019; Miszczuk \& Jakubowski, 2015; Jakubowski, Bronisz \& Miszczuk, 2017; Basboga, 2020). Nonetheless, these studies largely constitute case studies (Sohn \& Scott, 2020) or comparative studies (Scott, Sweedler, Ganster \& Eber- 
wein, 1997; Sohn, Reitel \& Walther, 2009; Decoville, Durand, Sohn \& Walther, 2013), whereas cross-cutting and holistic studies showing the development processes of cross-border areas in a broader perspective are still scarce. The few exceptions only seem to confirm the challenges and difficulties of cross-sectional analysis of the state and socio-economic changes in cross-border areas (Topaloglou, Kallioras, Manetos \& Petrakos, 2005; Sohn \& Licheron, 2018; Basboga, 2020). This is primarily because the study of cross-border areas presents a significant challenge of incomplete comparability of information and statistical data, as well as dispersion of data sources. Moreover, the processes taking place in cross-border areas are often significantly influenced by the geographical, historical, political, cultural, social, and economic context (Medeiros, 2020). Failure to take these aspects into account can significantly impoverish the research from a cognitive point of view, and sometimes even lead to erroneous results and drawing unwarranted conclusions.

There is also a lack of comprehensive works devoted not so much to the impact of European integration and Cohesion Policy on the development of cross-border areas, as to the impact of the aforementioned processes on overcoming developmental disparities in cross-border areas, i.e. the issues of asymmetry of economic development of cross-border areas and cross-border convergence. This generates the need for a broader diagnosis of this still largely unexplored phenomenon.

The study covered cross-border areas, i.e. areas located on both sides of the border whose axis is the state border, rather than border areas seen from the perspective of the centre of bordering countries (Gorzym-Wilkowski, 2005). The article aims to characterise the phenomenon, determine the level, as well as analyse the dynamics and directions of change in the level of asymmetry of economic development of cross-border areas in the European Union (EU), i.e. the disproportion of development between border areas located in two countries, based on GDP per capita (PPP). This allowed for the development of a typology of cross-border areas in the EU in terms of the aforementioned criteria and changes in the existing development disparities.

\section{Literature Review}

Due to factors such as geographical proximity, common historical experience, developed economic cooperation, and social contacts, in many cases areas located on both sides of the state border show certain shared features (Krätke, 1999; Perkmann, 2003). The combination of various natural, historical, geopolitical, and even civilisational conditions, and different dynamics and directions of socio-economic and political processes, however, sometimes leads to the formation of significant disparities in the level of their development, and substantial differences on other levels (Anderson \& O’Dowd, 1999; Krätke, 1999).

The term 'asymmetry' is a recurrent notion addressed in border studies. It is used among others by Anderson and O'Dowd (1999) who points to the existence of economic, political, cultural, and social asymmetries. Kawałko (2011) refers to the asymmetry of socio-economic systems and asymmetry of political systems. Oleński (2016) lists a whole range of dimensions of asymmetry that disintegrate the economy of cross-border regions, including asymmetry of potentials and capitals (social and human, technological, economic, and institutional), asymmetry of institutional arrangements and procedures, and asymmetry of resources. In addition to asymmetries in the level of economic development, Hardi (2017) also analyses asymmetries in cross-border interactions, including asymmetries in travel habits and personal relations. 
Asymmetry is commonly defined as lack of symmetry characterised by 'correspondence in size, shape, and relative position of parts on opposite sides of a dividing line or median plane or about a centre or axis' (MWD, 2020), with the national border being the axis in the case of cross-border areas. As indicated by Jańczak (2018), following this popular understanding, research on the asymmetry of borders and borderlands primarily uses a comparative approach to analyse differences in the potentials of areas located on two sides of a border, including economic potential. Asymmetry in border studies 'rarely refers to any specific understanding, conceptualization or theoretization of this category and is used as an equivalent of imbalance in some sectors' (Jańczak, 2018, p. 513). Other terms used in the literature to describe the analysed phenomenon include disproportion (Clement, 1997; Laine, 2012), imbalance (Decoville et al., 2013), or distance (Gorzelak, 2003). Against this background, the paper assumes that the concept of asymmetry of economic development of cross-border areas should be understood as the imbalance in the level of economic development (measured e.g. by the level of GDP per capita) of border areas of bordering countries located next to each other (Jakubowski, 2018a), conditioned by the asymmetry of potentials, capitals, resources, and institutional solutions (Laine, 2012; Oleński, 2016).

The phenomenon of asymmetry in the level of economic development of cross-border areas, as well as the very fact of its border location, creates specific, although difficult to define consequences for both sides of the border. On the one hand, it may become a source of opportunities for the economies of border regions, e.g. in the labour market. On the other hand, asymmetry may turn out to be a cause of challenges and threats for socio-economic systems on both sides of the border (Anderson \& O'Dowd, 1999; Agnew, 2008; Sohn, 2014). The existing developmental disparities may constitute a barrier that is difficult to overcome, limiting opportunities for the development of cross-border ties, particularly in terms of institutional cooperation (Miszczuk, 2013). On the other hand, under certain conditions, the existing differences in the level of development may become a key factor stimulating the growth of cross-border ties of functional nature, manifested in the intensification of flows, including increased cross-border trade and labour activity of the population (Nerb et al., 2009; Bergs, 2012; Decoville et al., 2013; Decoville \& Durand, 2019). For example, while differences in price levels can stimulate the development of economic cooperation, other differences, e.g. in the size and availability of financial resources, can be a significant barrier to the development of cross-border interactions (Laine, 2012). The level of disparity in the economic development of border areas (asymmetry of economic development) is also related to the very perception of border location as an 'opportunity' or 'threat' to regional development, with location next to a more developed area being considered an opportunity, and a less developed area - a threat (Jakubowski, 2018a).

The issue of changes in the level of asymmetry of economic development of cross-border areas (possible levelling or further deepening of developmental disproportions) is related to the dynamics of changes in the level of economic development of border areas. This, in turn, depends on a variety of factors and barriers to growth whose catalogue and nature of impact is somewhat different than in the case of other areas (Capello et al., 2018ab). According to Miszczuk (2013), the development of border regions is primarily a consequence of geopolitical conditions, related to the nature of relations between neighbouring states and their relations and position in the international environment, affecting the spatial-functional variability of state borders. Other factors with a significant impact in this respect include institutional (related to the existence of institutional and organisational distance), socio-demographic (related to multiculturalism and unfavourable demographic processes), and economic conditions resulting from the existing disparities in the economic systems and level of development of border regions. 
Many determinants and factors have contributed to the far-reaching transformations observed in the socio-economic situation and role of cross-border areas in the EU in recent decades (Fig. 1). One of the most important ones is globalisation which has led to an increase in international interdependence of regional economies (Konecka-Szydłowska, Churski, Herodowicz \& Perdał, 2019), shaping a new, more relational understanding of spatialities, including cross-border areas (Paasi, 2019). The opening up of regional economies and internationalisation of production processes, however, has led to the emergence of new spatial inequalities in economic production and income level (Ó Riain, 2011). It is often also discernible in cross-border areas.

The processes of globalisation remains strongly interdependent with the processes of economic integration (Konecka-Szydłowska et al., 2019). The EU common market, along with free movement of people, capital, goods, and services, has become a unique determinant of regional development and cross-border economic ties within the European integration process. Nonetheless, according to empirical studies, geographical proximity to the border often proves to be an insufficient factor to provide for high intensity of factor flows or trade relations across the border (Wróblewski, 2020).

Development of border areas in the EU is also significantly influenced by the Cohesion Policy, primarily aiming at strengthening economic, social, and territorial cohesion by reducing disparities in the level of development of European regions, primarily through support for the least favoured areas (OJ, 2012). This means that peripheral regions in the socio-economic dimension are the main focus of Cohesion Policy. Since 1990, when the Interreg programme was first carved out of the European Regional Development Fund, it has also included support for border areas, mainly through the development of cross-border cooperation. This provides for some opportunities to overcome the negative effect of the border on development processes, and to counteract their marginalisation (Ruidisch, 2013; Miszczuk \& Jakubowski, 2015; Medeiros, 2018a).

The collapse of the bipolar system and the process of European integration have also led to fundamental changes in the functions of borders and borderlands (Komornicki, 1999; O'Dowd, 2002; Więckowski, 2019) which may vary from 'barrier' to 'contact zone' (Ratti, 1993), and from separating to integrative (Martinez, 1994). Cross-border regions resulting from the opening of borders became 'spaces of communication, interaction, innovations, and development, [while] the EU enlargement to the east and the inclusion of most CEE [Central and Eastern European] countries in the Schengen zone accelerated the processes of re- and de-bordering, and diversification of the functions and regime of borders' (Kolosov \& Więckowski, 2018, p. 5).

A decrease in the level of border impermeability and their subsequent opening under the Schengen Agreement accelerated the processes of cross-border integration and regionalisation. Due to this, cross-border areas are sometimes referred to as laboratories of integration (Knippenberg, 2004). Durand and Perrin (2018) list four dimensions of cross-border integration: functional, institutional, structural, and ideational. The structural dimension, concerning the socio-economic and spatial characteristics of border areas, focuses on the degree of asymmetry and dynamics of convergence on both sides of the border.

Finally, cross-border cooperation itself, referring to a network of more or less formalised and flexible cross-border links between different categories of actors, such as public institutions, non-governmental organisations, entrepreneurs, etc., should be considered an important factor determining the contemporary dynamics of cross-border development (Durand \& Decoville, 2020). It fosters not only multifaceted strengthening of cross-border ties (Sousa, 2013), but also economic development of border areas (Basboga, 2020; Howaniec \& Lis, 2020). 


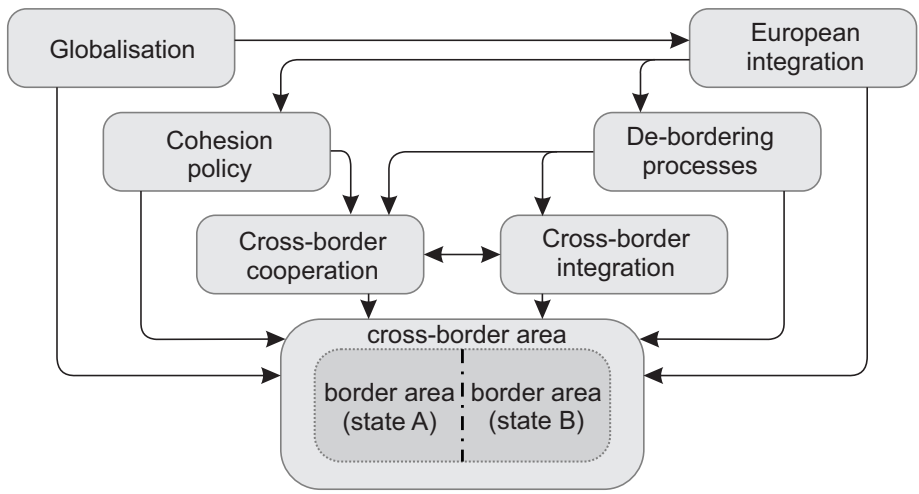

Figure 1. Main determinants and factors affecting the performance of cross-border areas in the EU Source: own elaboration.

This catalogue is of course not exhaustive. Each of the above factors, however, has a significant impact on the development of functional, and consequently institutionalised cross-border regions, increasing the regional growth potential of border areas (Klatt \& Winkler, 2020). Do the aforementioned changes lead to a reduction in the level of asymmetry in economic development and cohesion of cross-border areas? Despite the availability of numerous studies devoted to the development disparities at the level of countries and regions and convergence processes within the EU (Rey \& Montouri, 1999; Esposti \& Bussoletti, 2008; Wójcik, 2008; Pieńkowski \& Berkowitz, 2015; Jakubowski, 2018b), the question of changes in disparities in the level of economic development of cross-border areas remains largely open.

\section{Materials and Methods}

The study of changes in the level of asymmetry of economic development covered cross-border areas at the internal borders of the EU designated based on a division into NUTS 3 statistical units adjacent to the national border. Only land borders were taken into account, given the much weaker impact of border areas and the scale of cross-border connections in the case of maritime borders. This permitted identifying 36 cross-border areas within the EU, comprising 72 border areas .

The study was conducted for the period 1990-2015. The time frames of the study were conditioned by the availability of data in the European Regional Database 2017 developed by Cambridge Econometrics and the European Joint Research Council for the period 1980-2015 (ERD, 2018), and the merit-based criterion. The starting caesura is related to the initiation of dynamic socio-economic and political transformation processes in CEE countries associated with the collapse of the bipolar system. The period also saw the dynamisation of the process of political and economic integration within the existing and newly established structures of international cooperation (Konecka-Szydłowska et al., 2019), leading to the creation of the European Common Market and the EU (1993), as well as its several enlargements (1995, 2004, 2007 and 2013). The internal reforms of the European Economic Community, including the creation of the Cohesion Policy (1988) and the launch of the Interreg programmes (1989), are also of great importance in the context of the topic of this thesis. In justified cases (e.g. when the studied country was established after 1990, when data is missing or not comparable), the period of analysis for some 
cross-border areas was reduced accordingly (e.g. for the years 1993-2015, 1994-2015, 1995-2015 or 1996-2015).

The level of economic development of border areas was assessed based on the value of the GDP per capita, PPP based. Values of the indicator were calculated and respectively aggregated for each of the border areas of the individual countries included in the cross-border areas, delimited as characterised above. Data on GDP (nominal, 2005 constant prices) and population for the NUTS 3 units came from the European Regional Database (ERD, 2018). The obtained results were converted based on PPPs and historical national currency exchange rates from the Eurostat (Eurostat, 2020), Organisation for Economic Co-operation and Development (OECD, 2020), and International Monetary Fund (IMF, 2020) databases, and expressed in the so-called international dollars. Given the need to operationalise data at the sub-regional level in cross-border territorial systems, the use of GDP per capita (PPP) proved to be the best possible solution, despite its certain limitations as a measure of the level of economic development (Jakubowski, 2018b).

Subsequently, the level of asymmetry of economic development of individual border areas of the neighbouring countries was determined using the asymmetry index (Al). Assuming that $x_{i}<x_{j}$, where $x_{i}$ and $x_{j}$ denote GDP per capita (PPP) of border areas $i$ and $j$, the $A l$ in border area $i$ with respect to neighbouring border area $j$ is described by the following equation:

$$
A I=\left(1-\frac{x_{i}}{x_{j}}\right) \times 100 \%
$$

A value of $A l=0$ indicates full symmetry, while a value of $A l>0$ indicates asymmetry. $A l<0$ indicates asymmetry occurring in a situation in which a kind of role reversal took place - the initially less-developed border area $i$ achieved a higher value of GDP per capita (PPP) than the bordering area $j$. Calculations using the above-mentioned measure allowed for determining the dynamics and scale of change in the level of asymmetry in the development of cross-border areas in 1990-2015.

The next stage of the study involved typology of cross-border areas in Europe by asymmetry of the level of economic development. The typology was based on two criteria:

- the level of asymmetry of economic development in the starting year $\left(A I_{t 1}\right)$;

- the direction and dynamics of change in the asymmetry of economic development over the analysed period.

It was assumed that the group of symmetrical areas includes cases for which the value of the asymmetry index is in the range $[0,10]$. Six potential types of cross-border areas were designated according to the aforementioned criteria for typology presented in Table 1. 
Table 1. Criteria for typology of cross-border areas

\begin{tabular}{|c|c|c|}
\hline \multirow[b]{2}{*}{ Type of cross-border area } & \multicolumn{2}{|c|}{ Criterion of typology } \\
\hline & $\begin{array}{l}\text { Level of asymmetry of economic } \\
\text { development in the starting year } \\
\qquad\left(\mathrm{Alt}_{1}\right)\end{array}$ & $\begin{array}{l}\text { Direction and dynamics of } \\
\text { change in the asymmetry of } \\
\text { economic development over the } \\
\text { analysed period }\end{array}$ \\
\hline Symmetrical and keeping the distance & $A / t_{1} \in[0,10]$ & $A l_{2015} \in[-10,10]$ \\
\hline \multirow{3}{*}{ Symmetrical and diverging } & \multirow{3}{*}{$A / t_{1} \in[0,10]$} & $A l t_{1}-A I_{2015}<-10$ \\
\hline & & or \\
\hline & & $A l t_{1}-A I_{2015}>10$ \\
\hline Asymmetrical and keeping the distance & $A / t_{1}>10$ & $A l t_{1}-A I_{2015} \in[-10,10]$ \\
\hline \multirow{3}{*}{ Asymmetrical and converging } & $A / t_{1}>10$ & $A l t_{1}-A I_{2015}>10$ \\
\hline & \multicolumn{2}{|c|}{ or } \\
\hline & $A / t_{1}>10$ & $A I_{2015} \in[-10,10]$ \\
\hline Asymmetrical and diverging & $A / t_{1}>10$ & $A l t_{1}-A I_{2015}<-10$ \\
\hline $\begin{array}{l}\text { Asymmetrical with reversal } \\
\text { of relationship* }\end{array}$ & $A / t_{1}>10$ & $A I_{2015}>-10$ \\
\hline
\end{tabular}

* Type where the initially less developed border area of country A has over time reached a higher level of development than the neighbouring border area of country $B$.

Source: own elaboration.

\section{Results}

The first stage of the analysis allowed for tracing the directions and dynamics of changes in the asymmetry of the level of economic development of cross-border areas located at the internal borders of the EU. The results for individual cross-border areas are presented in Figure 2 . They indicate relatively high diversification of the scale of disproportions in the level of economic development of individual cross-border areas and the directions and intensity of changes in this respect.

This situation applies in particular to the analysed areas located in CEE countries between the so-called new EU member states, where dynamic convergence and divergence processes are observed, regardless of the scale of differences in GDP per capita (PPP) in the initial year. Some of the analysed border areas (e.g. Slovak-Polish, Polish-Czech, Slovak-Hungarian, Hungarian-Slovenian, or Croatian-Slovenian) are characterised by a relatively stable tendency towards convergence, while others (such as the Latvian-Lithuanian or Bulgarian-Romanian border area) show a tendency towards divergence.

Particularly dynamic changes in the level of asymmetry of economic development in the period 1990-2015 are shown by cross-border areas at the junction of the so-called old and new EU member states (for example the Polish-German, Slovak-Austrian, or Hungarian-Austrian borderland). An interesting characteristic of these cases is the intensifying asymmetry in the level of economic development until the EU enlargement in 2004 when this trend was broken and convergence progressed. These less developed border areas of the CEE countries can be therefore regarded as undisputed beneficiaries of European integration. To a limited extent, this applies to the Bulgarian-Greek border region, where slow reduction of disparities in economic development observed after 2008 seems to be not so much a consequence of Bulgaria's membership in the EU, but rather of the deep economic crisis in Greece. 


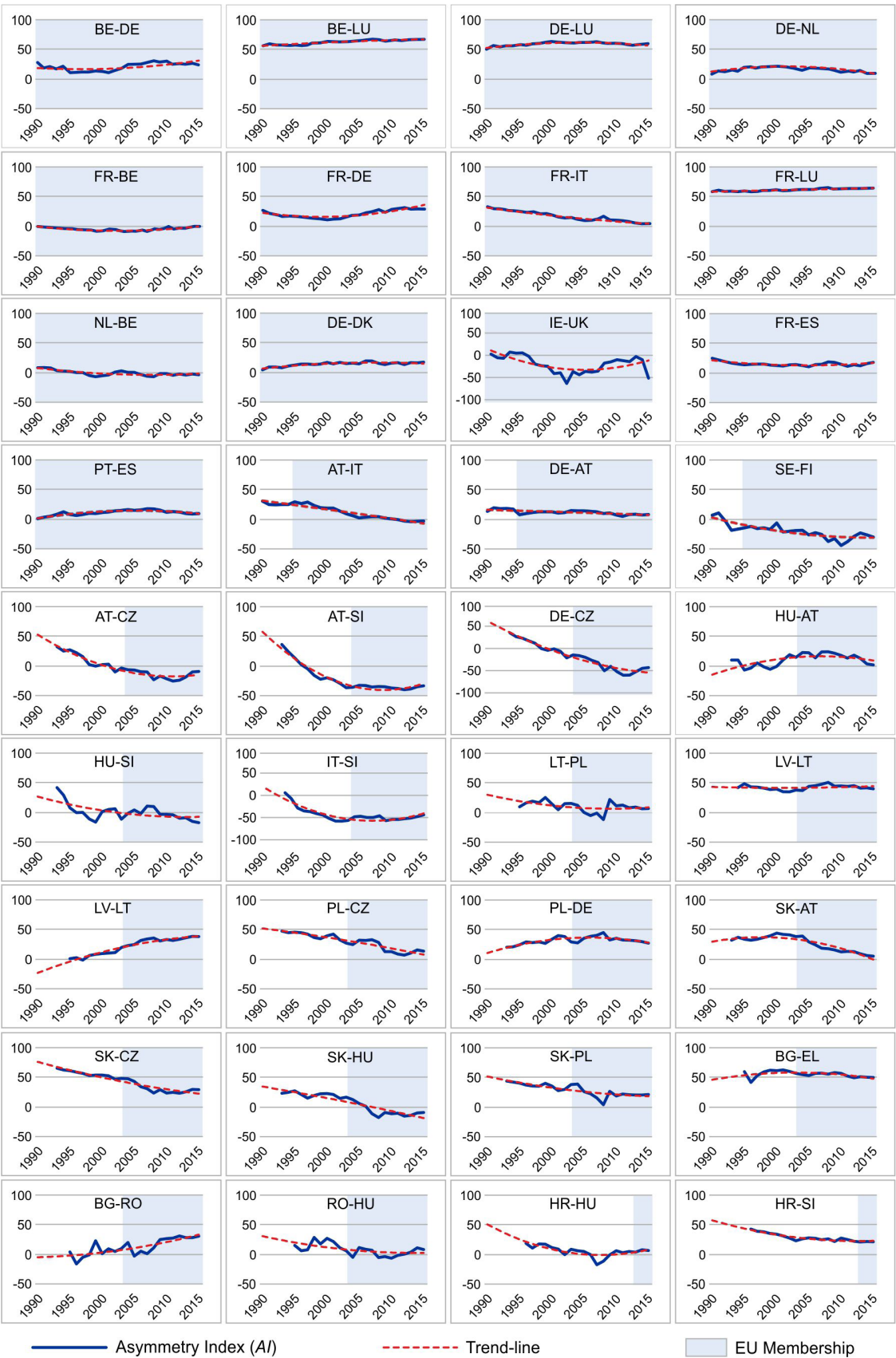

Figure 2. Asymmetry in the level of economic development of cross-border areas in the EU Source: own elaboration based on data of ERD (2018), Eurostat (2020), IMF (2020) and OECD (2020). 
On the other hand, cross-border areas on the internal borders of the so-called old EU member states are characterised by much lower dynamics of change, regardless of the level of development disproportions between them. This group includes cross-border areas with a very high level of asymmetry in the entire period covered by the analysis (which applies to all border areas of Luxembourg - with Germany, France, and Belgium), as well as cross-border areas with a similar level of economic development (the French-Belgian, Dutch-Belgian, and German-Austrian border areas). A steady trend of reducing disparities in the level of economic development (convergence) was observed for the French-Italian and Austrian-Italian borderlands. In 2015, they were characterised by almost complete symmetry in terms of GDP per capita (PPP). In contrast, the development trajectories of the French-German, Belgian-German, German-Dutch, and Irish-British borderlands were more complex. In the first and second case, a gradual process of convergence took place in the 1990s, almost leading to an equalisation of the level of economic development on both sides of the French-German and Belgian-German borders. This trend, however, was reversed in the 21 st century along with a steady increase in disparities. In the case of the German-Dutch and Irish-British borderlands, the opposite situation occurred. The value of the analysed asymmetry index increased until 2000-2002, followed by several years of diminishing differences in the level of development.

The analysis of changes in the value of the asymmetry index indicates relatively large differentiation of disproportions in the level of economic development of cross-border areas in the EU, as well as the directions of changes in this respect in the period 1990-2015. In order to organise the obtained results, a typology of EU cross-border areas was developed, taking into account the aforementioned criteria. This way, the following types of cross-border areas were designated:

1. Symmetrical and keeping the distance - i.e. areas showing a low level of asymmetry of economic development and stability in this respect. This category includes 6 cross-border areas: Lithuanian-Polish, German-Dutch, Dutch-Belgian, French-Belgian, Portuguese-Spanish, and IrishBritish. In addition to the Lithuanian-Polish border area, this category includes cross-border areas of countries that are longstanding members of the EU (with equal membership duration), characterised by cultural proximity, advanced cross-border integration processes, and large-scale functional links. Cross-border areas in this group show relative economic cohesion and have the best conditions for further development of cross-border cooperation and integration.

2. Symmetrical and diverging - i.e. areas with initially low levels of asymmetry of economic development and increasing disparities in development. Four cross-border areas were included in this category: German-Danish, Swedish-Finnish, Latvian-Lithuanian, and Bulgarian-Romanian). In all the cases, an increase in the level of asymmetry was caused by higher economic growth dynamics of one part of the cross-border area. In the case of the Swedish-Finnish and German-Danish border areas, this took place at a generally high growth rate of both parts of the cross-border areas in the analysed period. Despite increasing disparities, the German-Danish border area in particular is characterised by a high level of integration and good conditions for the development of functional links. In this case, increasing disparities could be explained by the one-sided cross-border approach in business, while the market size explains flows (Klatt \& Winkler, 2020). In the Latvian-Lithuanian and Bulgarian-Romanian borderlands, an increase in the level of asymmetry was a consequence of the dynamisation of development processes in one part of the borderland (respectively: Lithuanian and Romanian), and stagnation in the other (Latvian and Bulgarian).

3. Asymmetrical and keeping the distance - i.e. cross-border areas with a high level of asymmetry of economic development and no significant changes in this respect in the analysed period. This category includes eight cross-border areas: Belgian-German, German-Luxembourg, 
Belgian-Luxembourg, French-Luxembourg, French-German, French-Spanish, Latvian-Estonian, Polish-German, and Bulgarian-Greek. This category includes cross-border areas of the so-called old EU member states, as well as those of the new member states and those located at the interface between the old and new EU member states. In some cases, the reason for the persistence of significant disparities in the level of economic development in the aforementioned areas is significant asymmetry of structural and functional-spatial nature (e.g. in terms of population density, level of urbanisation and economic structure). Some of the areas included in this category (particularly the Greater Region of Luxembourg, covering the border between Luxembourg, France, Germany, and Belgium), despite the existing disparities, are characterised by a generally high level of economic development and a widely developed network of cross-border links, primarily including unidirectional functional links expressed in population flows (e.g. related to taking up employment).

4. Asymmetrical and converging - i.e. cross-border areas with a high level of asymmetry of economic development at the beginning of the analysis, and progressive reduction of disproportions in this respect. This group (the most abundant) includes 13 cross-border areas: French-Italian, Austrian-Italian, German-Austrian, Austrian-Hungarian, Austrian-Czech, Slovakian-Austrian, Slovakian-Polish, Polish-Czech, Slovakian-Czech, Slovakian-Hungarian, Romanian-Hungarian, Croatian-Hungarian, and Croatian-Slovenian. This category primarily includes borderlands located within the so-called new and between old and new EU member states. In most cases, proper targeting of subsidies from EU funds has had a fundamental impact on the observed catch-up effect (Goecke \& Hüther, 2016). The integration processes taking place in CEE countires since the beginning of the 1990s combined with accession to the $\mathrm{EU}$ and reduction of barriers resulting from the existence of traditional state borders certainly played a large, although difficult to define, role in dynamising the development processes of the weaker border areas in CEE. Some of these borderlands entered the path of convergence only after joining the EU. The German-Austrian and Austrian-Italian borderlands, on the other hand, show cultural proximity and close cross-border cooperation embedded in similar development conditions (ESPON, 2018).

5. Asymmetrical and diverging - i.e. cross-border areas with a high level of asymmetry of economic development and constantly growing disproportions in this respect. Considering the criteria adopted in this study, none of the cross-border areas covered by the analysis was qualified to this group. The Belgian-Luxembourg, French-Luxembourg, and German-Luxembourg border areas, however, show a high value of the asymmetry index of the level of economic development, and a constant upward trend in this respect. This makes them potential asymmetric and diverging areas.

6. Asymmetric with reversal of relationship - areas where the initially less-developed border area of country A has over time reached a higher level of development than the neighbouring border area of country B. This type includes a group of 4 cross-border areas: Czech-German, Italian-Slovenian, Austrian-Slovenian, and Hungarian-Slovenian. Although the distinction of this type is fully justified in theoretical and logical terms, its empirical verification based on the example of cross-border areas in the EU raises certain doubts. It is possible that the value of GDP per capita, PPP based for the analysed areas, and therefore the values of the asymmetry index, are burdened with slightly understated values of PPP conversion rates according to the OECD and IMF for Slovenia and Czechia for the 1990s, while the phenomenon of 'relationship reversal' is a kind of statistical effect.

Cartographic presentation of the obtained results, and the transboundary areas representing different designated types are shown in Figure 3. 


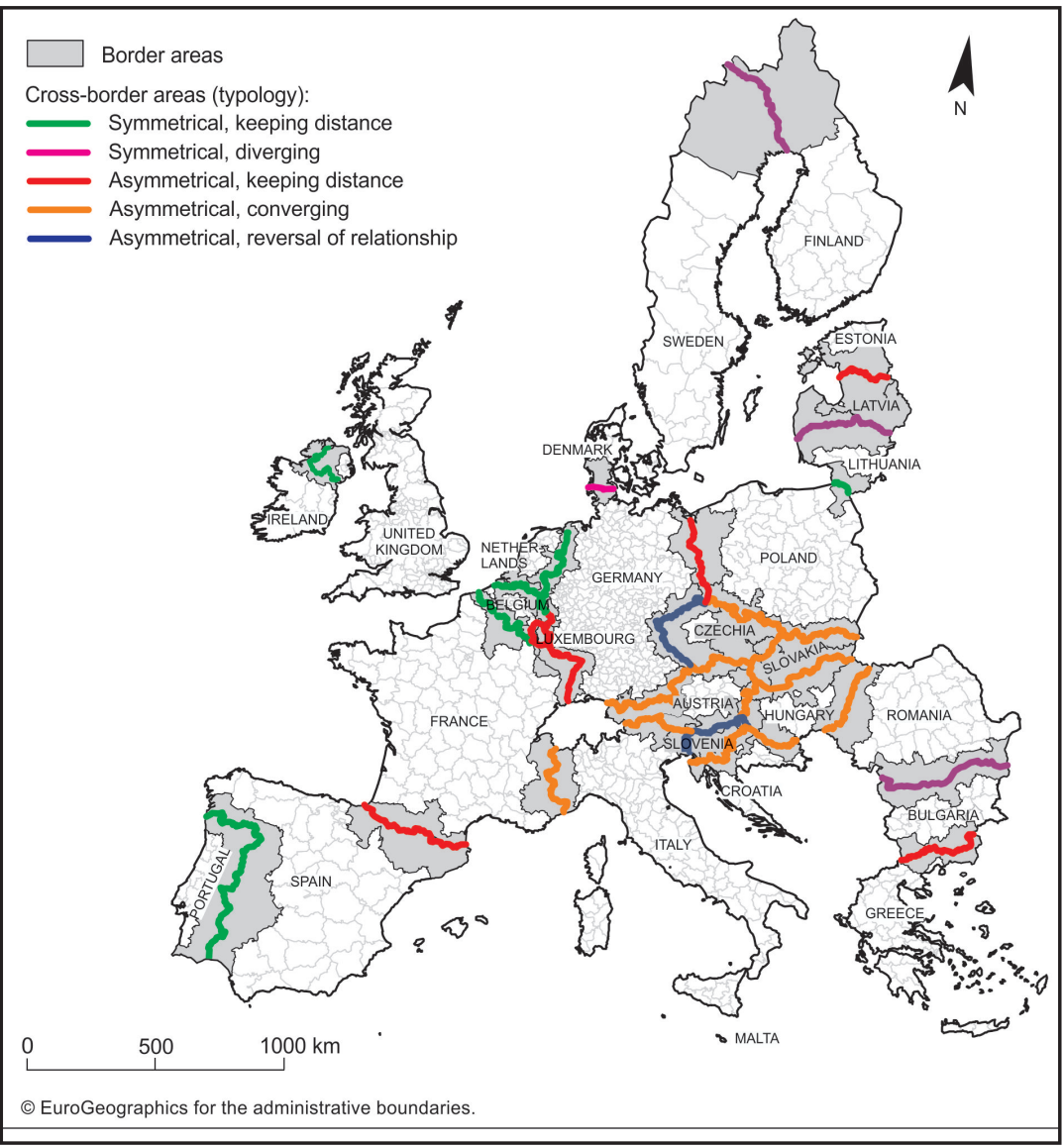

Figure 3. Types of cross-border areas in the EU by asymmetry of economic development Source: own elaboration based on data of ERD (2018), Eurostat (2020), IMF (2020) and OECD (2020).

\section{Discussion}

In the post-1990 period, the European continent experienced a dynamic course of megatrends such as globalisation, transformation, and economic integration (Konecka-Szydłowska et al., 2019), leading to an increase in international linkages and interdependencies. This period was also associated with far-reaching transformations in the functions of borders and borderlands, development of cross-border integration and cross-border cooperation, and implementation of relevant placebased policies, most notably the EU Cohesion Policy with the launch of Interreg programmes. These factors and conditions have had and continue to have a significant impact on the situation of European border areas, leading to important socio-economic transformations. Although an active European Cohesion Policy has been in place since the Delors reform in 1988, and its high profile has been confirmed by the Treaty provisions, the territory of the EU still shows large disparities in the level of economic development, both between countries and between regions, and the ex- 
isting development disparities are particularly evident at the junctions of neighbouring countries.

The study presented in this paper allowed for the determination of the scale and dynamics of changes in the asymmetry of the level of economic development of cross-border areas in EU countries in the period 1990-2015. The obtained results permitted proposing a typology of cross-border areas in Europe in terms of the asymmetry of economic development and direction of changes in this respect, as well as assigning individual cross-border areas to a specific type. The obtained results suggest that both the examined asymmetry phenomenon and intensity of convergence and divergence processes in the EU cross-border areas are characterised by high complexity and diversity, both spatially and temporally. Cross-border areas between the so-called old EU member states are generally characterised by lower dynamics of changes in terms of diversification of the level of economic development, although the development disproportions in some cases are quite significant. Much higher dynamics of economic growth, and therefore changes in the level of asymmetry, are observed at the junction of the old and new, and between the new EU member states.

Although in the vast majority of cases a trend leading to equalisation of the levels of economic development of border areas (convergence) is observed, there are examples of diverging border areas, i.e. those characterised by a successive increase in the existing disproportions. There are several possible reasons for this situation. It can be to some extent eluded by differences in the market size and economic forces according to the geo-economic model of integration proposed by Sohn (2014), or metropolisation processes and the core-periphery theory. This phenomenon will occur in cross-border areas characterised by particularly large discrepancies in economic potential. It can also be explained by the lack of a common vision for the development of the cross-border areas that would satisfy all partners (Sohn, 2014). This may result in inefficient management of the territorial capital of the entire cross-border region, unfavourable for balanced territorial development. Finally, referring to the assumptions and objectives of the Interreg programme, divergence may be the consequence of an unfinished process of cross-border integration, and the result of existing barriers due to the existence of a national border. This perspective suggests a need for further action to reduce border barriers.

The discussed issue becomes particularly relevant in the context of the new approach to programming the development of cross-border areas in the EU, outlined both in the Territorial Agenda 2030 (TA 2030, 2020) and in the Cohesion Policy and European Territorial Cooperation programming documents for 2021-2027 (EC, 2018b). They pay much more attention to the issue of cross-border functional links (including cross-border commuting), conditioned precisely by the asymmetry of economic development. According to Herzog and Sohn (2014), cross-border metropolitan areas should be the ones with the most to gain from the interplay between flows and the proximity of the state borders. On the other hand, the convergence of neighbouring areas can result precisely from the presence and development of cross-border interactions, contributing to the erosion of the existing disparities, as well as being a consequence of national development processes. As Cohesion Policy supports the development of cross-border cooperation, it may also paradoxically lead to a decrease in cross-border ties 'driven by asymmetries and complementarities' (Decouville et al., 2013).

The impact of the mere opening of national borders on the convergence of cross-border areas as well as the relationship between economic cohesion and cross-border functional linkages, however, has not been fully proven so far. One should probably agree with Sohn's statement (2014) that the relationship between economic disparities and different types of flows is not so clear-cut, and that cross-border linkages may in some conditions reinforce inequalities, while in others lead to their reduction. The obtained results allow for hypothesising that divergence occurs 
in areas characterised by unidirectional flows resulting from the existing significant disparities in the level of economic development. What seems certain, however, is that the very differentiation of the level of economic development of cross-border areas on the growth of border areas can only be revealed if the state border reaches a sufficiently high level of permeability (Ratti, 1993; Jakubowski, 2018b). In this context, the results seem to confirm the prediction made by Topaloglou et al. (2005) that border regions of new member states bordering old EU members should benefit most from membership.

The study expands our knowledge on the correlation between open borders, European integration, and Cohesion Policy, and their impact on overcoming development disparities in EU's cross-border areas. It confirms the generally positive impact of the aforementioned processes on economic convergence which can be regarded as an underlying objective of the Cohesion Policy, and cross-border cooperation under Interreg in particular. Differences between individual cross-border areas in terms of performance, persistence of asymmetry, and even divergence in some cases, suggest that support for cross-border development and cross-border cooperation must be context-specific and address border-specific problems. This points to the even greater importance of place-based policy and integrated cross-border planning (Tölle, 2013; Durand, 2014; Zaucha, Komornicki, Böhme, Świątek \& Żuber, 2014). A potential solution addressing this issue could also be the establishment of a European cross-border mechanism that would allow for legislative convergence (EC, 2018a), considering the existence of legal and administrative international barriers, substantially affecting the economic growth of the border regions (Camagni, Capello \& Caragliu, 2019).

\section{Conclusions}

The results presented in this paper may be regarded a starting or reference point for further research taking into account the quantitative and qualitative aspects of the performance of cross-border areas. Those studies should allow for more detailed and multifaceted identification of factors determining the phenomenon of asymmetry of socio-economic development, and the course of convergence and divergence processes in cross-border areas, identified based on the findings presented in this paper.

The study results also permitted formulating additional research questions concerning the phenomenon of asymmetry of the economic development of cross-border areas, and identification of further research directions. Firstly, the answer to the question of whether $\mathbf{B}$-convergence (unconditional and conditional) and $\sigma$-convergence occurs in EU cross-border areas could be obtained through more sophisticated econometric analysis. Secondly, there is a need to determine the impact of European integration and the related processes of opening of national borders and development of cross-border ties on cross-border convergence or divergence processes in cross-border areas, and other factors (geographical, social, economic, political) that influence cross-border convergence and divergence processes. Bearing in mind that development processes in border areas remain dependent on the performance of states, it is important to identify to what extent cross-border convergence and divergence processes constitute a function of economic development in bordering countries. An interesting research topic would be to attempt to determine the extent to which the activation of less developed areas in cross-border systems is determined by interregional policies of the EU and the neighbouring countries, and by intraregional policies conducted from the level of administrative regions. Finally, additional in-depth analysis of the role 
of the EU Cohesion Policy in overcoming the asymmetry of economic development in cross-border areas is needed.

The obtained results lead to the conclusion that despite a fairly evident reduction of the level of asymmetry of development of cross-border areas in many cases in the period 1990-2015, and particularly after 2004, many cross-border areas show significant disparities in the economic sphere, significantly influencing many aspects of their performance and the shape of cross-border relations. In the context of cohesion as an objective of the EU regional policy, it seems justified that its programming should place greater emphasis on reducing disparities not only in development in the pan-European (inter-state) and intra-state (inter-regional) dimensions, but also in the cross-border system. It also seems appropriate to reorient cross-border cooperation programmes which by supporting the development of cross-border ties should focus more on cross-border cohesion - not only in the economic, but also in the social and territorial dimension.

\section{Acknowledgement}

The study presents the results of the research project 'Processes of cross-border convergence in the conditions of the European integration' financed by the National Science Centre (Poland) based on decision No. 2018/02/X/HS4/01728 as well as the research project 'Asymmetry of the economic development of cross-border areas' financed by the Faculty of Earth Sciences and Spatial Management, Maria Curie-Skłodowska University, with the grant-in-aid of the Ministry of Science and Higher Education 'Young personnel and PhD students' based on decision No. BS-M-12-011$18-\mathrm{H}-01$.

\section{References}

Agnew, J. (2008). Borders on the mind: Re-framing border thinking. Ethics \& Global Politics, 1(4), 175191. https://doi.org/10.3402/egp.v1i4.1892

Anderson, J., \& O'Dowd, L. (1999). Borders, Border Regions and Territoriality: Contradictory Meanings, Changing Significance. RegionalStudies, 3(7), 593-604. https://doi.org/10.1080/00343409950078648

Anderson, J., O'Dowd, L., \& Wilson, T. M. (Red.). (2003). New Borders for a Changing Europe: Cross-border cooperation and Governance. London: Routledge.

Basboga, K. (2020). The role of open borders and cross-border cooperation in regional growth across Europe. Regional Studies, Regional Science, 7(1), 532-549. https://doi.org/10.1080/21681376.2020 .1842800

Bergs, R. (2012). Cross-border Cooperation, Regional Disparities and Integration of Markets in the EU. Journal of Borderlands Studies, 27(3), 345-363. https://doi.org/10.1080/08865655.2012.751710

Blatter, J. (2004). From 'spaces of place' to 'spaces of flows'? Territorial and functional governance in cross-border regions in Europe and North America. International Journal of Urban and Regional Research, 28(3), 530-548. https://doi.org/10.1111/j.0309-1317.2004.00534.x

Blatter, J., \& Clement, N. (2000). II Introduction to the Volume: Cross-Border cooperation in Europe: Historical development, institutionalization, and contrasts with North America. Journal of Borderlands Studies, 15(1), 14-53. https://doi.org/10.1080/08865655.2000.9695541

Camagni, R., Capello, R., \& Caragliu, A. (2019). Measuring the impact of legal and administrative international barriers on regional growth. Regional Science Policy \& Practice, 11(2), 345-366. https://doi. org/10.1111/rsp3.12195

Capello, R., Caragliu, A., \& Fratesi, U. (2018a). Measuring border effects in European cross-border regions. Regional Studies, 52(7), 986-996. https://doi.org/10.1080/00343404.2017.1364843 
Capello, R., Caragliu, A., \& Fratesi, U. (2018b). Breaking Down the Border: Physical, Institutional and Cultural Obstacles. Economic Geography, 94(5), 485-513. https://doi.org/10.1080/00130095.2018 .1444988

Clement, N. (1997). The Changing Economics of International Borders and Border Regions. In P., Ganster, A., Sweedler, J. W., Scott \& W.-D., Eberwein (Eds.). Borders and Border Regions in Europe and North America (pp. 47-63). San Diego, CA: San Diego State University Press.

Decoville, A., \& Durand, F. (2019). Exploring cross-border integration in Europe: How do populations cross borders and perceive their neighbours? European Urban and Regional Studies, 26(2), 134-157. https://doi.org/10.1177/0969776418756934

Decoville, A., Durand, F., Sohn, C., \& Walther, O. (2013). Comparing Cross-border Metropolitan Integration in Europe: Towards a Functional Typology. Journal of Borderlands Studies, 28(2), 221-237. https://doi.org/10.1080/08865655.2013.854654

Durand, F. (2014). Challenges of Cross-Border Spatial Planning in the Metropolitan Regions of Luxembourg and Lille. Planning Practice \& Research, 29(2), 113-132. https://doi.org/10.1080/02697459. 2014.896148

Durand, F., \& Decoville, A. (2020). A multidimensional measurement of the integration between European border regions. Journal of European Integration, 42(2), 163-178. https://doi.org/10.1080/070 36337.2019.1657857

Durand, F., \& Perrin, T. (2018). Eurometropolis Lille-Kortrijk-Tournai: Cross-border integration with or without the border? European Urban and Regional Studies, 25(3), 320-336. https://doi. org/10.1177/0969776417704688

EC (2018a). Proposal for a Regulation of the European Parliament and of the Council on a mechanism to resolve legal and administrative obstacles in a cross-border context. COM/2018/373 final.

EC (2018b). Proposal for a Regulation of the European Parliament and of the Council on specific provisions for the European territorial cooperation goal (Interreg) supported by the European Regional Development Fund and external financing instruments. COM/2018/374 final.

ERD (2018). European Regional Database 2017. European Commission - Joint Research Centre; Cambridge Econometrics. Retrieved from http://urban.jrc.ec.europa.eu/t-pedia/\#/

ESPON (2018). Common spatial perspectives for the Alpine area. Towards a common vision. Retrieved from https://www.espon.eu/sites/default/files/attachments/01_alps_2050_FR_main_report.pdf

Esposti, R., \& Bussoletti, S. (2008). Impact of Objective 1 Funds on Regional Growth Convergence in the European Union: A Panel-data Approach. Regional Studies, 42(2), 159-173. https://doi. org/10.1080/00343400601142753

Eurostat (2020). Former euro area national currencies vs. Euro/ECU - annual data. Eurostat Database. Retrieved from https://appsso.eurostat.ec.europa.eu/nui/show.do?dataset=ert_h_eur_a\&lang=en

Goecke, H., \& Hüther, M. (2016). Regional Convergence in Europe. Intereconomics, 51(3), 165-171. https://doi.org/10.1007/s10272-016-0595-x

Gorzelak, G. (2003). Bieda i zamożność regionów: Założenia, hipotezy, przykłady. Studia Regionalne i Lokalne, 11(1), 37-59.

Gorzym-Wilkowski, W. A. (2005). Region transgraniczny na tle podstawowych pojęć geograficznych Próba syntezy. Przeglaqd Geograficzny, 2(77), 235-252.

Hardi, T. (2017). Asymmetries in the Formation of the Transnational Borderland in the Slovak-Hungarian Border Region. In E., Boesen \& G., Schnuer (Eds.). European Borderlands: Living with Barriers and Bridges (pp. 176-192). London: Routledge.

Herzog, L. A., \& Sohn, C. (2014). The Cross-Border Metropolis in a Global Age: A Conceptual Model and Empirical Evidence from the US-Mexico and European Border Regions. Global Society, 28(4), 441461. https://doi.org/10.1080/13600826.2014.948539

Howaniec, H., \& Lis, M. (2020). Euroregions and Local and Regional Development - Local Perceptions of Cross-Border Cooperation and Euroregions Based on the Euroregion Beskydy. Sustainability, 12(18), 7834. https://doi.org/10.3390/su12187834

IMF (2020). Implied PPP conversion rate. International Monetary Fund. Retrieved from https://www.imf. org/external/datamapper/PPPEX@WEO/OEMDC/ADVEC/WEOWORLD/SAU 
Jakubowski, A. (2018a). Asymmetry of Economic Development of Cross-Border Areas in the Context of Perception of Near-Border Location. Barometr Regionalny. Analizy i Prognozy, 16(2), 123-131.

Jakubowski, A. (2018b). Convergence or Divergence? Multidimensional Analysis of Regional Development in the New European Union Member States. Barometr Regionalny. Analizy i Prognozy, 16(1), 31-40.

Jakubowski, A., Bronisz, U., \& Miszczuk, A. (2017). Polityka Spójności oraz Europejski Instrument Sąsiedztwa i Partnerstwa jako narzędzia wsparcia współpracy transgranicznej na wewnętrznych i zewnętrznych granicach Unii Europejskiej. Roczniki Nauk Społecznych, 9(3), 73-89. https://doi. org/10.18290/rns.2017.45.3-5

Jańczak, J. (2018). Symmetries, asymmetries and cross-border cooperation on the German-Polish border. Towards a new model of (de)bordering. Documents d'Anàlisi Geogràfica, 64(3), 509-527.

Kawałko, B. (2011). Wybrane problemy polsko-ukraińskiej współpracy transgranicznej. Barometr Regionalny. Analizy i Prognozy, 2(24), 35-60.

Klatt, M., \& Winkler, I. (2020). Lessons from the Danish-German Border Region for Post 2020 Interreg A - an Alignment with Cross-Border Functional Regions? Europa XXI, 38. https://doi.org/10.7163/ Eu21.2020.38.5

Knippenberg, H. (2004). The Maas-Rhine Euroregion: A Laboratory for European Integration? Geopolitics, 9(3), 608-626. https://doi.org/10.1080/14650040490478675

Kolosov, V., \& Więckowski, M. (2018). Border changes in Central and Eastern Europe: An introduction. Geographia Polonica, 91(1), 5-16. https://doi.org/10.7163/GPol.0106

Komornicki, T. (1999). Granice Polski. Analiza zmian przenikalności w latach 1990-1996. Warsaw: IGiPZ PAN.

Konecka-Szydłowska, B., Churski, P., Herodowicz, T., \& Perdał, R. (2019). Europejski kontekst wpływu współczesnych megatrendów na rozwój społeczno-gospodarczy. Ujęcie syntetyczne. Przegląd Geograficzny, 91(2), 39-59. https://doi.org/10.7163/PrzG.2019.2.3

Krätke, S. (1999). Regional Integration or Fragmentation? The German-Polish Border Region in a New Europe. Regional Studies, 33(7), 631-641. https://doi.org/10.1080/00343409950078675

Laine, J. (2012). Border Paradox: Striking a Balance between Access and Control in Asymmetrical Border Settings. Eurasia Border Review, 3(1), 51-79.

Martinez, O. J. (1994). The Dynamics of Border Interaction. New Approaches to Border Analysis. In C., Schofield (Ed.). World boundaries, global boundaries (pp. 1-15). London: Routledge.

Medeiros, E. (2015). Territorial Impact Assessment and Cross-Border Cooperation. Regional Studies, Regional Science, 2(1), 97-115. https://doi.org/10.1080/21681376.2014.999108

Medeiros, E. (2018a). The Role of European Territorial Cooperation (ETC) in EU Cohesion Policy. In E., Medeiros (Ed.). European Territorial Cooperation. Theoretical and Empirical Approaches to the Process and Impacts of Cross-Border and Transnational Cooperation in Europe (pp. 69-93). Cham: Springer.

Medeiros, E. (2018b). Should EU cross-border cooperation programmes focus mainly on reducing border obstacles? Documents d'Anàlisi Geogràfica, 64(3), 467. https://doi.org/10.5565/rev/dag.517

Medeiros, E. (2019). Cross-border transports and cross-border mobility in EU border regions. Case Studies on Transport Policy, 7(1), 1-12. https://doi.org/10.1016/j.cstp.2018.11.001

Medeiros, E. (2020). Delimiting cross-border areas for policy implementation: A multi-factor proposal. European Planning Studies, 28(1), 125-145. https://doi.org/10.1080/09654313.2019.1687654

Miszczuk, A. (2013). Uwarunkowania peryferyjności regionu przygranicznego. Lublin: Norbertinum.

Miszczuk, A., \& Jakubowski, A. (2015). Evolution of the European Union Cohesion Policy Towards Border Regions. In A. J., Kukuła (Ed.). Cohesion policy and development of the European Union's regions in the perspective of 2020 (pp. 169-191). Lublin: Wydawnictwo KUL.

MWD (2020). Merriam-Webster Dictionary. Retrieved from https://www.merriam-webster.com/dictionary/asymmetry

Nerb, G., Hitzelsberger, F., Woidich, A., Pommer, S., Hemmer, S., \& Heczko, P. (2009). Scientific Report on the Mobility of Cross-Border Workers within the EU-27/EEA/EFTA Countries. Munich: MKW Wirtschaftsforschung. Retrieved from https://ec.europa.eu/futurium/en/system/files/ged/mkw_ workers_mobility.pdf

Niebuhr, A. (2004). Spatial Effects of European Integration: Do Border Regions Benefit Above Average? (HWWA DISCUSSION PAPER). Hamburg Institute of International Economics. 
Niebuhr, A., \& Stiller, S. (2004). Integration and Labour Markets in European Border Regions. HWWA Discussion Paper, 284. Hamburg: Hamburg Institute of International Economics.

Ó Riain, S. (2011). Globalization and regional development. In A., Pike, A., Rodriguez-Pose \& J., Tomaney (Ed.). Handbook of Local and Regional Development (pp. 17-29). London: Routledge.

O'Dowd, L. (2002). The Changing Significance of European Borders. Regional \& Federal Studies, 12(4), 13-36. https://doi.org/10.1080/714004774

OECD. (2020). PPPs and exchange rates. OECD. Retrieved from https://stats.oecd.org/OECDStat_Metadata/ShowMetadata.ashx?Dataset=SNA_TABLE4\&ShowOnWeb=true\&Lang=en

OJ (2012). Treaty on European Union and the Treaty on the Functioning of the European Union. Official Journal of the European Union, C 326, 26/10/2012 P. 0001 - 0390.

Oleński, J. (2016). Typology of Transborder Economies and the Need of Transborder Statistics in Globalized World. International Journal on Transborder Economics, Politics and Statistics, 1(1), 9-32.

Paasi, A. (2019). Borderless worlds and beyond: Challenging the state-centric cartographies. In A., Paasi, E.-K., Prokkola, J., Saarinen, \& K., Zimmerbauer (Eds.). Borderless Worlds for Whom? Ethics, Moralities and Mobilities (pp. 21-36). London: Routledge.

Perkmann, M. (2003). Cross-border Regions in Europe: Significance and Drivers of Regional Cross-Border Cooperation. European Urban and Regional Studies, 10(2), 153-171. https://doi. org/10.1177/0969776403010002004

Pieńkowski, J., \& Berkowitz, P. (2015). Econometric assessments of Cohesion Policy growth effects: How to make them more relevant for policy makers? Working Paper, 02/2015. European Commission. Retrieved from https://ec.europa.eu/regional_policy/sources/docgener/work/2015_02_econ_assess.pdf

Ratti, R. (1993). Spatial and Economic Effect of Frontiers. Overview of Traditional and New Approaches and Theories of Border Area Development. In R., Ratti \& S., Reichmann (Eds.). Theory and Practice of Transborder Cooperation (pp. 23-53). Basel und Frankfurt am Main: Helbing \& Lichtenhahn.

Rey, S. J., \& Montouri, B. D. (1999). US Regional Income Convergence: A Spatial Econometric Perspective. Regional Studies, 33(2), 143-156. https://doi.org/10.1080/00343409950122945

Ruidisch, R. (2013). Territorial Cohesion and Border Areas. In A., Lechevalier \& J., Wielgohs (Eds.). Borders and Border Regions in Europe: Changes, Challenges and Chances (pp. 95-110). Bielefeld: Transcript Verlag.

Scott, J. W., Sweedler, A., Ganster, P., \& Eberwein, W. D. (1997). Dynamics of Transboundary Interaction in Comparative Perspective. In P., Ganster, A., Sweedler, J. W., Scott \& W. D., Eberwein (Eds.). Borders and Border Regions in Europe and North America (pp. 3-23). San Diego, CA: San Diego University Press.

Sohn, C. (2014). Modelling Cross-Border Integration: The Role of Borders as a Resource. Geopolitics, 19(3), 587-608. https://doi.org/10.1080/14650045.2014.913029

Sohn, C., \& Licheron, J. (2018). The multiple effects of borders on metropolitan functions in Europe. Regional Studies, 52(11), 1512-1524. https://doi.org/10.1080/00343404.2017.1410537

Sohn, C., \& Scott, J. W. (2020). Ghost in the Genevan borderscape! On the symbolic significance of an "invisible" border. Transactions of the Institute of British Geographers, 45(1), 18-32. https://doi. org/10.1111/tran.12313

Sohn, C., Reitel, B., \& Walther, O. (2009). Cross-Border Metropolitan Integration in Europe: The Case of Luxembourg, Basel, and Geneva. Environment and Planning C: Government and Policy, 27(5), 922939. https://doi.org/10.1068/c0893r

Sousa, L. D. (2013). Understanding European Cross-border Cooperation: A Framework for Analysis. Journal of European Integration, 35(6), 669-687. https://doi.org/10.1080/07036337.2012.711827

TA 2030 (2020). Territorial Agenda 2030: A Future for All Places. Retrived from https://www.territorialagenda.eu/home.html

Tölle, A. (2013). National Planning Systems Between Convergence and Incongruity: Implications for Cross-Border Cooperation from the German-Polish Perspective. European Planning Studies, 21(4), 615-630. https://doi.org/10.1080/09654313.2012.722957

Topaloglou, L., Kallioras, D., Manetos, P., \& Petrakos, G. (2005). A border regions typology in the enlarged European Union. Journal of Borderlands Studies, 20(2), 67-89. https://doi.org/10.1080/08865655. 2005.9695644 
Więckowski, M. (2019). Od barier i izolacji do sieci i przestrzeni transgranicznej - konceptualizacja cyklu funkcjonowania granic państwowych. Przeglqd Geograficzny, 91(4), 443-466. https://doi. org/10.7163/PrzG.2019.4.1

Wójcik, P. (2008). Dywergencja czy konwergencja? Dynamika rozwoju polskich regionów. Studia Regionalne i Lokalne, 32(2), 41-60.

Wróblewski, Ł. D. (2020). Cross-border ties in the light of the EU common market. Border \& Regional Studies, 8(4), 187-205. https://doi.org/10.25167/brs2199

Zaucha, J., Komornicki, T., Böhme, K., Świątek, D., \& Żuber, P. (2014). Territorial Keys for Bringing Closer the Territorial Agenda of the EU and Europe 2020. European Planning Studies, 22(2), 246-267. https://doi.org/10.1080/09654313.2012.722976 